\title{
Wineries in a Medieval Hillfort Aktobe
}

Yeleuov M.

Department of Archeology, Ethnology and Museology of the al-Farabi Kazakh National University Almaty, Kazakhstan

Akymbek Y.

Master of Archeology and Ethnology, Historian, Ethnologist, Institute of Archaeology of Named After A.Kh. Margulan Almaty, Kazakhstan; eraly_a@mail.ru

\section{Doi:10.5901/mjss.2015.v6n6s2p40}

\section{Abstract}

\begin{abstract}
Medieval hillfort settlement of Aktobe was located at a lowland of rivers Sargay, Aksu, Kara-Balta and Toktash. They fall into the middle reach of the Chu River that takes off from the Kyrgyz Ala-Too Range. The settlement of Aktobe existed in 6th-8th centuries. Similarly to all the medieval towns, it took up a lot of land and consisted of a citadel, shakhristan (a part of town within a defensive wall, but outside of the citadel) and rural area. Latter was located within a 2-7 km radius from the middle part of the settlement, on the left bank of the Aksu river. It was fenced off with a rampart, left from the defensive wall. Town activity was centred at the rural area. Archaeologists excavated this site in order to find out the purpose of the buildings and type of farming that required the use of irrigation ditches in the rural area. After years of research - in 1979 and 2007 - scientists found several estates as well as remnants of two small workshops built of sun-dried earth brick and rammed clay, looking quite similar. On the basis of building features scientist came to a conclusion that they were wineries. Wineries are dated 11th-12th centuries. From there, we may say that inhabitants of medieval Aktobe practiced viniculture. Thus, this article directly deals with archaeological excavations at the sites of workshops and their description.
\end{abstract}

Keywords: the Middle Ages, Aktobe, hillfort, rural area, winery, pottery.

\section{Introduction}

Medieval Aktobe hillfort is located to the south of the Aksu village, Shu District, Jambyl Region, the Republic of Kazakhstan. Having long defensive walls, it consists of three parts: citadel, shakhristan (a part of town within a defensive wall, but outside of the citadel) and rural area [Baipakov, 2011]. The rural area is surrounded with ramparts several kilometres long. The most part of rural area is located between the Aksu and Kara-Balta rivers. At present a rampart that used to be a double-row wall of outer fence still exists. Length of the inner rampart is $14770 \pm 5$ meters, height is $3 \mathrm{~m}$ (with sections up to $3.5 \mathrm{~m}$ ) width is $18-20 \mathrm{~m}$. Remains of the moat are still visible on the outer side: its width is 8-10 $\mathrm{m}$ and depth $-0.6-0.8 \mathrm{~m}$. The length of the second outer rampart is $20515 \pm 5 \mathrm{~m}$ with different degree of integrity. South-east side of the rampart is in the best condition, other parts are very low and damaged. Town life was mostly centred here, in the rural area. There are remnants of buildings in the form of big and small elevations, maked at aerial macro and micromaps of 1980 [Shalekenov, 2007]. Some of them are detached elevations, located in rows by 8-10. Among them there are complexes of residential homes, intersecting and continuing each other. Rows of elevations located close to each other form chains. Some elevations, connected by ramparts, have open ground in the centre. Grounds are divided into squares of different size; the tuffets in the ground's corners are connected with ramparts. There are remnants of numerous irrigation ditches around elevations with grounds. Ditches are 0.8-1.2 $\mathrm{m}$ wide with depth up to 0.1-0.5 $\mathrm{m}$. Elevations with a ground in the centre are often found to the west and south-west from the centre of the settlement. This part of the hillfort has remnants of large ditches from the Aksu and Kara-Balta rivers [Groshev, 1986]. Fresh water supply system of the settlement also was sourced here. Scientists excavated this area to find out the type of buildings under the tuffets in the rural area and kind of plants grown by the ditches.

\section{Research Method and Theoretical Foundations}

First workshop. In 1979 experts from the Department of Archaeology and Ethnography of the S.M. Kirov Kazakh National University (at present Al-Farabi Kazakh National University) began to study the south-west part of the hillfort - a group of 
tuffets in the rural area. Group of archaeologists excavated one of detached tuffets with the surface of $10 \times 8 \mathrm{~m}$ and height of $0.9 \mathrm{~m}$. Excavations revealed a place of an intriguing building with a room and a corridor [Shalekenov, 1980].

The room is square, surface area is $5.1 \times 4.1 \mathrm{~m}$. Walls are made of rammed clay, width is $0.9 \mathrm{~m}$, height (survived) 0.5-0.6 m. Flooring: sun-dried earth brick, size $41 \times 20.5 \times 10 ; 42 \times 22 \times 9-10 \mathrm{~cm}$. By the western wall there is a fireplace (oval cavity) with following dimentions: depth $0.15 \mathrm{~m}$, length $0.4 \mathrm{~m}$, width $0.2 \mathrm{~m}$. The fireplace was filled with ashes, a fragment of a caldron was lying by it.

The corridor adjoins the room from the south and is connected to it by a passage. Width of the corridor is $1 \mathrm{~m}$, length is not clear.

There is an interesting fact to mention: after a short period of time (occupation layer did not develop on the floor) first flooring was covered with a second layer made of rammed clay $(0.15 \mathrm{~m}$ thick). Over the second layer the partitions were built (0.2-0.4 $\mathrm{m}$ wide). These partition walls divided the room into 4 separate rooms, serving as working premises of a wine-maker's workshop (Pic. 1. 1), as it was found out later.
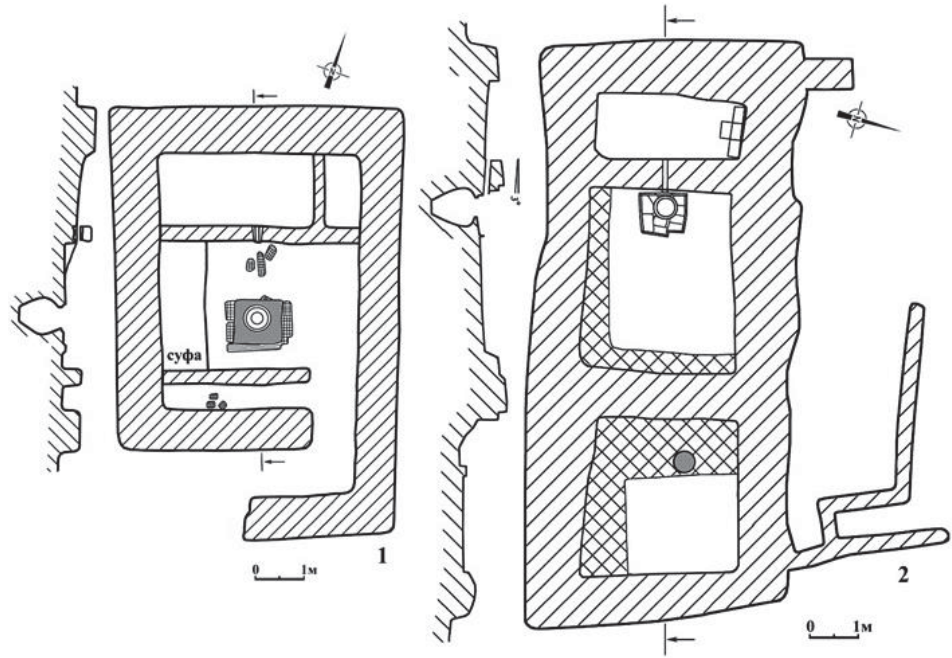

Picture 1. Wineries

Room 2 has the area of $3.2 \times 1.5 \mathrm{~m}$. Inner wall surface and floor still have remnants of alabaster coating (3 layers, 0.8-1 $\mathrm{cm}$ thick in total). North wall of the building goes down in slight sloping steps, so the floor level by the south wall is $0.2 \mathrm{~m}$ lower than by the north wall. South wall is upright. A clay pipe with a diameter of $13.4 \mathrm{~m}$ issues from the foundation of the south wall. The length of the pipe is $0.33 \mathrm{~m}$, it connects room 2 with room 3. Room $1(1.5 \times 0.75 \mathrm{~m})$ adjoins room 2 from the eastern side. They are divided with a partition made of rammed clay $(0.2 \mathrm{~m}$ wide). Flooring of room 1 is made with rammed clay and $0.3 \mathrm{~m}$ higher that floor in room 2.

Room $3(4.1 \times 2.6 \mathrm{~m})$ adjoins rooms 1 and 2 from the south. Floor level is $0.2 \mathrm{~m}$ lower than in room 2 . In $1.1 \mathrm{~m}$ from the north wall there is a $1.9 \times 0.9 \mathrm{~m}$ platform made of burnt bricks (of size $31.5 \times 19.5 \times 2.5 ; 32 \times 20 \times 3 ; 33.5 \times 18.5 \times 3 ; 37.18 .3 .5$ $\mathrm{cm}$ ). Sides are bricked with one layer. In the middle of the platform there is a khum sank into the floor (the rim is $5 \mathrm{~cm}$ lower than the surface of the platform). The platform surface and the khum rim is coated with three layers of alabaster (0.8-1 $\mathrm{cm}$ thick).

From the mouth of clay pipe, going from room 2 to the platform, there is a slope, where whole and broken burnt bricks used to be (size of bricks is mentioned above). Front side of the bricks still has remnants of alabaster coating. Along the western wall there is a sufa (a cott) made of rammed clay (width $1 \mathrm{~m}$, height $0.2 \mathrm{~m}$ ).

Room 4 is narrow and long, looks like a storehouse, adjoining room 3 . It is $3 \mathrm{~m}$ long and $0.5 \mathrm{~m}$ wide. There were 3

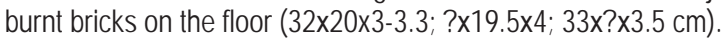

Thus, we come a conclusion that an excavated building apparently used to be habitual in its original form. Although, the only testimonial of it is the fireplace in the western part of the building.

Second period of use of the building begins with the second flooring and reconstruction of building in order to use it 
as a winery. All four rooms were related to winemaking or storage of wine and grapes.

Wine production was performed in rooms 2 and 3. Room 2 was filled with grapes and tramped, then grape juice through a clay pipe, built in the wall, drained by chute into the khum, sank in the floor. We may suggest that rooms 1 and 4 were service rooms, used to store grapes and wine.

Excavations revealed several fragments of pottery on the surface of both layers of flooring (pic. 2). There is no difference between pottery of both periods of building use, so we give its general description.

Pottery is represented by the khum, a jug, a cresset and fragments of a caldron and a lid.

The khum is sank into the floor. It has a rim (triangle in section), beveled outwards, with a diameter of $49 \mathrm{~cm}$. The height of khum is $94 \mathrm{~cm}$, its walls are $1.4 \mathrm{~cm}$ thick. Clay body is thick, blended with sand. On the outside khum is covered with grey engobe (pic. 2, 1). Similar khums are known to be present in the pottery of medieval Kulan, dated $11^{\text {th }}-12^{\text {th }}$ centuries. [Baipakov, 1972].

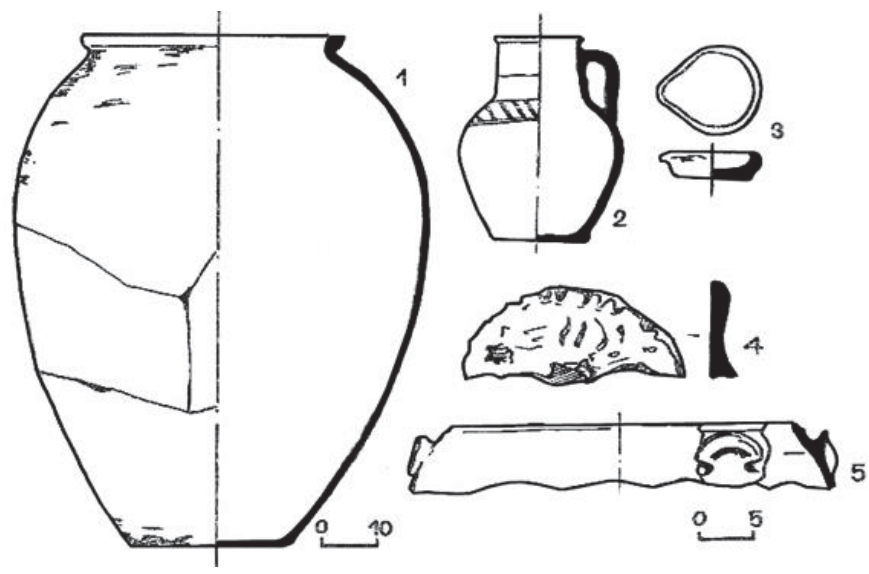

Picture 2. Pottery

A jug: wide-mouth, egg-shaped, tapering to the bottom. Mouth is $9 \mathrm{~cm}$ wide. Handle is crank: its upper end is attached under the rim, lower end - to the upper part of the body. Upper part of the body has a carved ornament on (pic. 2, 2). Similar jugs were found in the hillfort of Aktobe, in pottery of $10^{\text {th }}-12^{\text {th }}$ centuries [Kozhemyako, 1963] and in the pottery of Kulan [Baipakov, 1970].

A fragment of a cauldron of manual cast (pic. 2, 5), diameter $-32 \mathrm{~cm}$, rim bent inside, walls are $1 \mathrm{~cm}$ thick. The cauldron is made of thick clay body, blended with sand and rotted rock. Outer surface is sooty, inner surface was covered with a thin layer of grey washed clay before firing. Similar cauldrons were found in the Zhaksylyk hillfort [Bubnova, 1959], in the layers of $10^{\text {th }}-12^{\text {th }}$ centuries in settlements of the Talas valley [Kabanov, 1974]. Quite alike cauldrons were also found in $11^{\text {th }}$ century layer in Afrasiyab [Shalekenov et al, 1978].

A lid is represented by its half. It is a disk of $23 \mathrm{~cm}$ in diameter, manually shaped from clay body blended with sand. There are remnants of a handle - a Y-shaped piece of clay body attached to the disk. Outer surface of the lid is ornamented with finger dents: there is a sign of two parallel lines made in moist clay by fingernails, along the ridge of the lid there are dents made by fingers (pic. 2, 4). Similar lids were found in the settlement under study [Shalekenov et al, 2008].

A hand-moulded cresset has a drip, pulled with fingers. Rim diameter $-8 \mathrm{~cm}$ (pic. 2, 3).

Second workshop. In 2007 an archaeological expedition of the A. Kh. Margulan Institute of Archaeology started excavating one of the elevations in $1.5 \mathrm{~km}$ to the Southeast from the settlement centre.

Scientist started to dig an elevation in the northern part of the ground, surrounded with remnants of irrigation ditches. Its length is $23 \mathrm{~m}$ (from East to West), width - $14 \mathrm{~m}$, height $-1,5 \mathrm{~m}$. Excavations fully revealed remnants of buildings, used as a production, i.e. winemakery [Bubnova, 1963]. A four-cornered building was $12.3 \mathrm{~m}$ long and $5.5 \mathrm{~m}$ wide, had 3 rooms with walls, oriented at four cardinal directions (pic. 1, 2). Walls are made of rammed clay and are 1-1.2 $\mathrm{m}$ thick. Remnants of the walls are $0.5-0.6 \mathrm{~m}$. Places for doors to the rooms, having higher floor level, were ruined. There are remnants of buildings, which stretched to the North from the north-eastern corner. The building is open, so we may 
suggest that it was used as preconstruction hovel. Rooms are opened from West to East.

Area of the room 1 in the western part of the building is $3 \times 1.3 \mathrm{~m}$. Four burnt bricks on the floor along the northern wall remain intact. Size of bricks lying from East to West: $34.5-35 \times 18-19 \times 3.5 \mathrm{~cm}$. Bricks are laid tightly with alabaster coating. Bricks of other parts were not preserved, i.e. they were recovered. Ridge of the wall is reveted with burnt bricks on edge. It is proved by fragments of burnt bricks on edge in the south-west corner of the room. Floor level is $10 \mathrm{~cm}$ lower by a hole in the middle of the eastern wall - it opens into a nest room.

Area of the room 2 is $3.8 \times 3 \mathrm{~m}$. There are sufas $0.4 \mathrm{~m}$ wide and $0.3 \mathrm{~m}$ high in eastern and southern walls of the room. Floor is covered with a layer of clay $1.5-2 \mathrm{~cm}$ thick. A wall between room 1 and room 2 is $0.6 \mathrm{~m}$ thick, built of sundried earth brick (size of bricks $41 \times 21 \times 10 ; 42 \times 22 \times 9-10 \mathrm{~cm}$ ). Other end of the hole in the wall with the room 1 there is a clay pipe. Length of pipe is $39 \mathrm{~cm}$, edge diameter by the wall is $14.8 \mathrm{~cm}$, other edge diameter is $12.4 \mathrm{~cm}$, pipe walls are $0.6-1.9 \mathrm{~cm}$ thick. $3.2 \mathrm{~cm}$ below the pipe opening by the wall at the floor level there is a platform of burnt brick with $1 \times 0.9 \mathrm{~m}$ area (size of bricks $34.5-35 \times 18-19 \times 3.5 \mathrm{~cm}$ ). Edges of the platform are reveted with burnt bricks on edge. Bricks on edge rise over general level by $8-10 \mathrm{~cm}$. Bricks are laid tightly with alabaster coating (edges and corners are also covered with alabaster). In the centre of western edge of the platform there is a big khum sank into the floor to be at the same level. Inner height of the khum is $94 \mathrm{~cm}$, rim diameter $-49 \mathrm{~cm}$, diameter of inner base plate is $27 \mathrm{~cm}$, inner diameter of rising edge is $70 \mathrm{~cm}$.

Area of room 3 in the eastern part of the building is $3.2 \times 3 \mathrm{~m}$. Thickness of walls $-0.8-1.2 \mathrm{~m}$, height $-0.2-0.3 \mathrm{~m}$. Poor remnants of the sufa. In the middle of western sufa there are traces of burnt wood and ashes at the fireplace of 45 $\mathrm{cm}$ in diameter. At the top storey of the building there are remnants of a tandoor and utensil (probably, a caldron and a mortar).

Outside of the south wall of the building there is a destroyed wall ( $2 \mathrm{~m}$ away).

Rooms of the building were used as work-rooms for grapes tramping in order to get pekmez (grapes juice). All 3 rooms are associated with juice-making or storage of juice and wine. Process of winemaking was done in rooms 1 and 2. At first, room 1 was filled with grapes, then the juice dripped through the pipe into the khum, sank into the floor by the western wall in room 2.

Excavations revealed much of pottery, represented for the most part by khums, jugs, caldrons, mugs and lids.

Mugs. A mug is a cone with slightly inbent walls (diameter $12.4 \mathrm{~cm}$, height $5.6 \mathrm{~cm}$, bottom diameter $5 \mathrm{~cm}$ ). (Pic. 3 , 3). Similar mugs were found in the settlement Medieval Aktobe 1 (Kyrgyzstan), in $11^{\text {th }}-12^{\text {th }}$ century layer [Shalekenov, 1986]: a form of upturned cone, loop-shaped handle, slightly bent rim, $16 \mathrm{~cm}$ in diameter, $7 \mathrm{~cm}$ high, $4.6 \mathrm{~cm}$ in bottom diameter (pic. 3, 1). Similar mugs were also found in layer of $11^{\text {th }}-12^{\text {th }}$ centuries in Shakhristan in 1985 [Shalekenov, 1987].

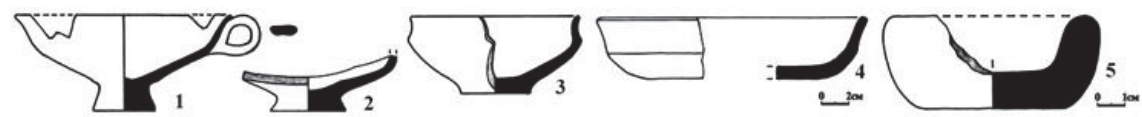

Picture 3. Mugs

Cressets. Handmade, evenly burnt. Form: low flat vessel. Rim diameter: $8 \mathrm{~cm}$. Height: $3.3 \mathrm{~cm}$ (pic. 3, 5).

Dishes. Made with the help of a whetting stone, evenly burnt. Colour: light-orange. Low, with flat bottom, walls are slightly undulating. Diameter of straight rim $-20 \mathrm{~cm}$, height: $4.5 \mathrm{~cm}$ (pic. 3,4 ).

Handles of caldrons. A caldron has handles in form of a single-piece arc (its ends are pressed to the caldron by fingers (pic. 4, 1-2, 4). A handle in the form of a crescent is fully attached to the caldron wall (pic. 4,3), and arc handles are squeezed with fingertips along their whole length (pic. 4, 5). Scientist have found several types of caldrons, all of them ball shaped and differing by rims and handles. Caldrons with wide rim have crescent handles, pitched to the walls, with diameter of inbent rim on $20 \mathrm{~cm}$ (pic. 4, 7, 10). Caldrons with arc handles, attached by fingertips sqeezing, have rim diameter of $20 \mathrm{~cm}$ (pic. 4, 8). Caldrons with handles that are a little rounded with wawes and traces of fingers, have rim diameter of $19.5 \mathrm{~cm}$ (pic. 4, 9). Excavation of a citadel in 1986 revealed a caldron with arc handles looking like a twisted thread in the $11^{\text {th }}-12^{\text {th }}$ century layer [Shalekenov, 1989]. 


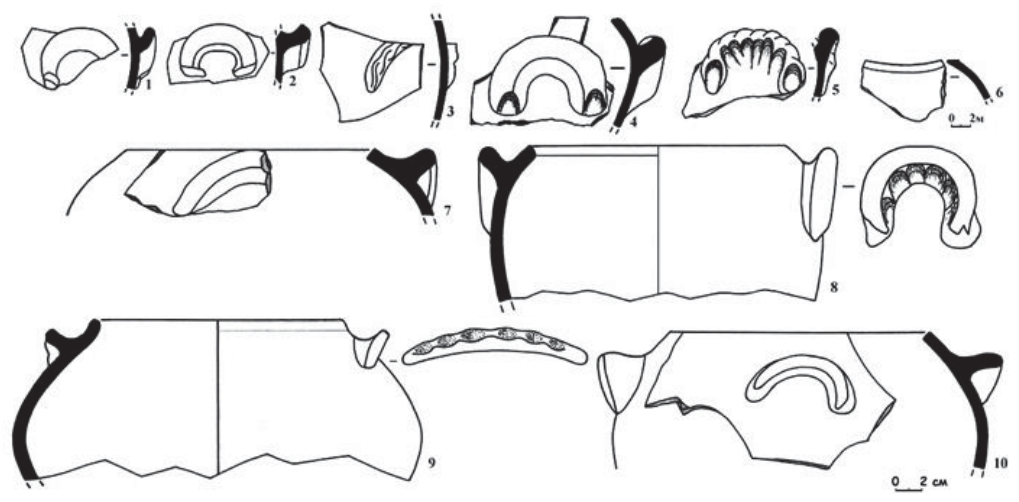

Picture 4. Caldrons

Excavations revealed several types of lid handles. They are: with flat top; tapering down; straight cylinder top; with a cutout centre in the upper part; lids with top in the form of a protruding cylinder; oblongated lids with indented or cut-out centre (for easy use). Some lids are decorated with lines made by a reed cane (pic. 5,9) and drawing like sign "+" (pic. 5,11). Lids with criss-cross lines were found in Shakhristan in $9^{\text {th }}-13^{\text {th }}$ century layer in 1988 [Shalekenov, 1978].

Lids. Majority of lids are flat, only one is bent (pic. 5, 8). They have different decoration patterns: 1 . Lids with fully decorated top and sides (pic. 5, 4-7). 2. Lids with decorated top (pic. 5, 1, 8, 10). 3. Lids with decorated sides (pic. 5, 2, 9, 11). 4. Lids with no decoration (pic. 5, 3). Decorations are made with the help of a feather, some hard object and fingers; people traced, pressed and punctured floral and geometric forms. There are also lids with outlined patterns. Diameters of lids: $15.5-38.5 \mathrm{~cm}$. Fragments of lids present a half $(48 \%)$ of all the objects found upon excavations. A layer of $10^{\text {th }}-12^{\text {th }}$ century of the settlement contains the most of lids [Shalekenov, 1980].
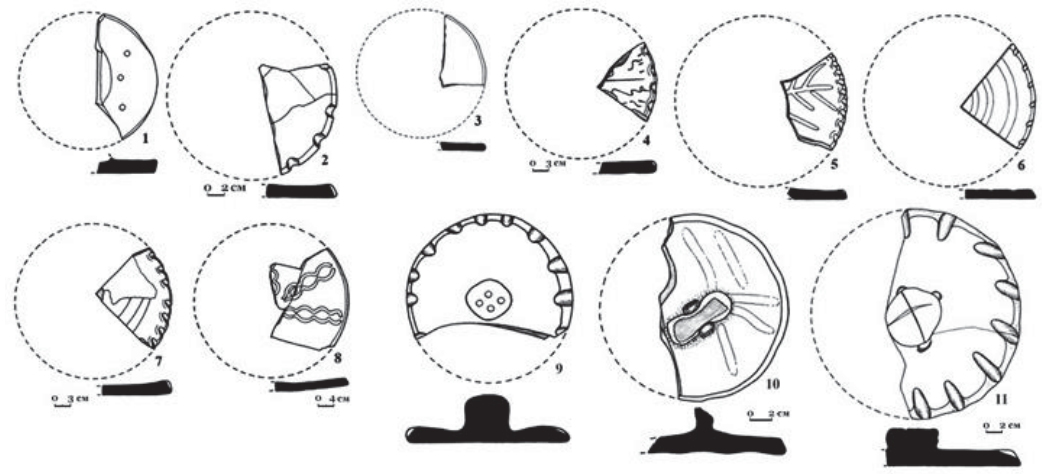

Picture 5. Lids

Pot rims. All pots are wheel-thrown and evenly burnt. Pot walls are convex. Rim is long drawn and belted with cross prolonged knot, the middle of which is squeezed out with fingers. There are also low pots with convex walls and straight (from the outside) rim; outer rim diameter is $18 \mathrm{~cm}$, inner diameter $-17 \mathrm{~cm}$.

Jugs. All jugs are wheel-thrown and evenly burnt. Colour: yellowish-red, whitish. Walls are thick, with rim thickened towards the top (diameter $9.6 \mathrm{~cm}$ ). Loop-shaped handles are attached closer to the rim with one end and to the body of the jug with the other. Handles have transversal holes of $0.4 \mathrm{~cm}$ in diameter. Other jugs have wide sides and long drawn straight rim, diameter $10.8 \mathrm{~cm}$. Loop-shaped handle is attached closer to the rim with one end and to the body of the jug with the other. In $5.5 \mathrm{~m}$ to the West from the winery a jug of $37 \mathrm{~cm}$ in diameter was found. It has a low neck and widened rim. From the rim outwards there is a rounded drain. Loop-shaped handle is attached to the upper part with one end and to the body of the jug with the other (pic. 6, 1). 


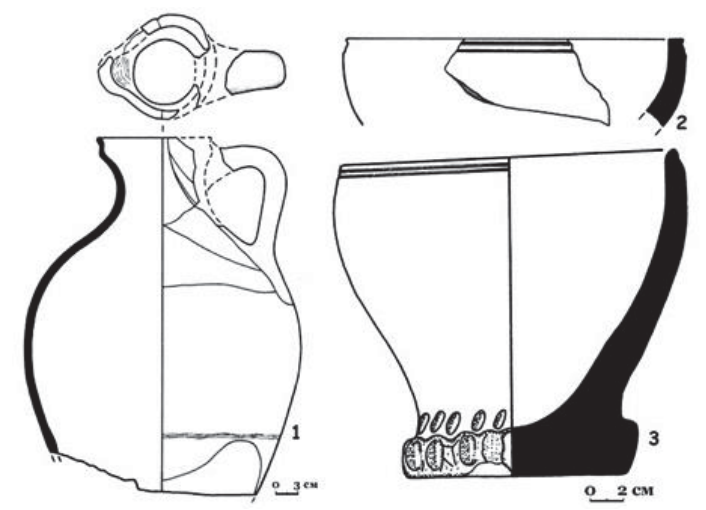

Picture 6. A jug and mortars

Mortar. Wheel-thrown, well burnt. A vessel with thick walls, deep bottom and straight rim (diameter: $20 \mathrm{~cm}$ ). Below the rim there are two rows of lines (pic. 6, 2-3). Other jug, better preserved, is $19.6 \mathrm{~cm}$ high. Edges of base and junction are decorated with patterns, made by fingertips indents (pic. 6, 2). In 1979 in $0.6 \mathrm{~km}$ to the South from the citadel to archaeologist often found vessels with similar ornament in $10^{\text {th }}-11^{\text {th }}$ century layer [Zuev, 2002].

\section{Contrastive Analysis}

In medieval towns, located in the Kazakhstan territory, winegrowing and production of vine-products were well developed. It is also confirmed by the Chinese calendar. Yu.A. Zuev in his works presented translations of Chinese manuscripts, in which travellers mention wine and grapes. For example, Xuanzang ( $7^{\text {th }}$ century) visited reception by the Turkic Khagan and tells: "The Khagan ordered to serve wine and start music. After that, the Khagan and all his people began to drink wine, but a religious mentor was offered something different - grape juice. Then people started to treat each other, pouring wine in goblets and cups and exchanging them". He also tells that the guest were offered meat of spring lamb and veal, and a religious mentor had delicate food made of rice-flour, cheese flatbread, honey and grapes (after the food was finished, grape juice was served again). In his chronicles Xuanzang tells that the land from Aksu to Tashkent is good for growing of grapes and millet, and that land of Nuchket is very humid, which is good for arable farming - there is a lot of soft grass, trees, flowers, vegetables and even highly valued grapes [Zuev, 1960].

Du Huan manuscripts contain information about Central Asia of $8^{\text {th }}$ century under ruling of Chinese commander Gao Xianzhi and the town of Talas: "From here to the Western Sea from the third to the ninth month there are no rains, and the fields are watered with snow melt. Here people grow barley, wheat, rice, pea and beans. People drink grape and hemp wines and ayran" [Dictionary of Ancient Turkic Language, 1969].

Lands, described in abovementioned Chinese chronicles were not far from the settlement under study - Aktobe. So, Chinese written texts of $7^{\text {th }}-8^{\text {th }}$ centuries say that winegrowing was very well developed in Turkic Khaganate. Wineries $\left(11^{\text {th }}-12^{\text {th }}\right.$ century), found in Aktobe hillfort, bespeak the fact that winegrowing was the main type of agriculture.

Also, in ancient Turkic written artifact of $7^{\text {th }}-13^{\text {th }}$ centuries there are several words, associated with grapes [Baipakov, 2004]. Below are listed the words, found in ancient Turkic chronicles, the meaning of which is associated with grapes, grape harvesting, grape tramping, grape juice and wine, its sale, sellers and retailer:

ADAQLïQ - rough workpieces for wooden poles, used in supporting frames in vineyards and as a base for a wickiup.

BAঠIČ (?) - a vine.

BANZÏ - rest of grapes on vine after the harvesting.

BEKMÄS - grape syrup.

$\mathrm{BOR}-$ wine.

BORLUQ - vineyard.

BUDA - grape.

BÜŠINČÄK - a cluster of grapes.

ČAYİR - grape juice, green wine. 
IDIŠČI - a cupbearer.

MANDU - grape vinegar of a peculiar recipe.

SÏQMAN - grape tramping season.

SÜRMÄ - wine.

ŠÄRAB - a drink.

ŠIRÄ - grape juice, green wine.

TAPČAN - a three-legged tabouret used in harvesting when bushes are tall.

TIM - 1) a bota bag filled with wine; 2) a wine merchant.

TIMČI - a wine merchant.

On the basis of the words found we arrive at a conclusion that wine-making was a very important part of the life of Turkic people.

Supposition as to the high level of development of winegrowing and winemaking is also supported by artefacts, found by researchers in medieval significant sites of Chu and Talas. Excavations of residential homes in Kostobe (Jamukat) ( $8^{\text {th }}$-9th centuries) revealed wall paintings, representing a vine and a vine-leaf [Baipakov, 1964]. Also, scientists found workhouses where grape juice was made [Senigova, 1972] (in residential complex B in Kulan, now Lugovoe), places of wine production in Nizhny Baryskhan [Bernshtam, 1950] and two workshops in Saryk (Saryg).

\section{Conclusion}

Location of medieval hillfort Aktobe - in a valley at the bottom of Ala-Too, Kyrgyzstan - was advantageous for irrigated agriculture. Rivers Kara-Balta and Aksu were used for watering of cultivated land of the settlement. There are remnants of irrigation ditches - large and small - from both rivers. Despite the fact that both rivers have their sources in the mountains, Kara-Balta had less water and was shallower than Aksu. Source of Aksu is located deep in the mountain region. In summer water level is higher due to melt water from the mountains, so the level was lower in winter. From the left side of Aksu starts a wide and deep ditch: at the point where it reaches the settlement, its width is 1.5-3 m and depth $-1-2 \mathrm{~m}$. It is obvious that the ditch was renewed several times. Main ditch gives start to subsidiary ditches, which irrigate several sections divided into squares. In the area of second workshops the width of preserved ditches with earthworks is $1 \mathrm{~m}$, depth $-0,4 \mathrm{~m}$. Evidences, revealed by excavations of the places of vineries, support the supposition that buildings in the rural area are of top occupation layer of $11^{\text {th }}-12^{\text {th }}$ centuries. So, excavations revealed that remnants of buildings in the rural area are dated $7^{\text {th }}-12^{\text {th }}$ century. In some open buildings - except the vineries - remnants of dwelling complexes and homes were found. Some of them belong to two occupation layers and, therefore, to two archaeological horizons. Most of buildings are located at the south-eastern, southern, western and north-western parts of the hillfort. To be more specific, we should say that the most of buildings are located by irrigation ditches. Reasoning from this fact, it is clear that inhabitants of medieval hillfort Aktobe at those centuries practiced winegrowing in the rural area.

Process of wine or juice making required 2 rooms: the first was covered with burnt brick with waterproof alabaster coating - there the grapes were treaded. Then the juice through a clay pipe drained into a vessel sank into the floor in the second room (volume of vessel was 70-80 litres). The vessel is also surrounded by coated burnt brick to prevent spilling of juice, and the vessel was a little inclined to make juice pour back. Peculiarities of construction prove that this workshop was quite large for those times. No doubt that excavations of elevations directly related to the vineries can reveal many interesting facts for the Kazakh archaeology.

\section{References}

Baipakov K.M, Erzakovich L.B. Some Results of Excavations in Zhaksylyk Settlement. In the Trail of Ancient Kazakhstan Art. Almaty, 1970. P. 34, pic. 13, 9-10.

Baipakov K.M, Ternovaya G.A. Carved Pottery of Zhetysu. Almaty: Credo, 2004. P. 5-19.

Baipakov K.M. Excavations of Medieval Workshop in Semirechye. Bulletin of KazSSR Academy of Sciences, No. 7, 1964. P. 88-91.

Baipakov K.M. Pottery of Medieval Kulan. Search and Findings in Kazakhstan. Almaty, 1972. P. 95.

Baipakov K.M., Kapekova G.A., Voyakin D.A., Maryashev A.N. 2011. Treasure of Ancient And medieval Taraz and Zhambyl Region, p. 435-451.

Bernshtam A.N. The Chuy Valley. International News Agency, No. 14, 1950. P. 44, 46, Table VII, 5, 90.

Bubnova M.A. Madieval Workshop of Rabad. Izvestiya, KyrSSR Academy of Sciences. Vol. 1, Frunze, 1959, p. 56; p. 57, pic. 6.

Bubnova M.A. Medieval Settlement Aktobe 1 by Orlovka village. Archeological Monuments of the Talas Valley. Frunze, 1963. Pic. 13, $87,91$.

Dictionary of Ancient Turkic Language. Leningrad: Nauka, 1969. 677 p. 
Groshev V.A. Irrigation of Aktobe (the Chuy Valley), Medieval Towns of South Kazakhstan. Almaty: KSU. 1986. P. 129-137.

Kabanov S.K., Filonovich M.I., Urmanova M.Kh. Excavating a Part of Residential Area of $9^{\text {th }}-11^{\text {th }}$ cent. Afrasiyab, Tashkent, 1974. No. III, p. 81, pic. 6,4 .

Kozhemyako P.N. Sedentary Settlements of the Talas Valley. Archeological Monuments of the Talas Valley. Frunze, 1963. P. 159, Table. V.

Senigova T.N. Medieval Taraz. Almaty: 1972. P. 68

Shalekenov U.Kh. Scientific Report. Archaeological Excavations of Medieval Hillfort Aktobe in 1979. Archives of Institute of Archaeology named after A. Kh. Margulan. Almaty, 1980. Office 2, case 1751. P. 31-34.

Shalekenov U.Kh. Settlements of Balasagun, $5^{\text {th }}-13^{\text {th }}$ cent. Almaty, 2007. P. 89.

Shalekenov U.Kh. Report: Archaeological Research of the Chuy Valley (1985). Archives of Institute of Archaeology named after A. Kh. Margulan. Almaty, 1986. P. 27-41.

Shalekenov U.Kh. Report: Archaeological Research of the Chuy Valley and East Kazakhstan (1986). Archives of Institute of Archaeology named after A. Kh. Margulan. Almaty, 1987. P. 8. Pic. 9, 5.

Shalekenov U.Kh. Report: Archaeological Research of the Chuy Valley (1988). Archives of Institute of Archaeology named after A. Kh. Margulan. Almaty, 1989. P. 5. Pic. 7, 4.

Shalekenov U.Kh. Scientific Report. Archaeological Excavations of Medieval Hillfort Aktobe in 1978. Archives of Institute of Archaeology named after A. Kh. Margulan. Almaty, 1978. P. 57. Pic. 20.

Shalekenov U.Kh. Scientific Report. Archaeological Excavations of Medieval Hillfort Aktobe in 1979. Archives of Institute of Archaeology named after A. Kh. Margulan. Almaty, 1980. P. 21. Pic. 25, 17; pic. 29, 12, 13.

Shalekenov U.Kh., Eleuov M., Aldabergenov N.O. Excavations of the Citadel of the Aktobe Settlement. Issues of History of Socialism and Communism Development in Kazakhstan. Almaty, 1978. P. 176.

Shalekenov U.Kh., Nurzhanov A.A., Akymbek E. Sh. Scientific Report. Archaeological Excavations of Medieval Hillfort Aktobe in 2002. Archives of Institute of Archaeology named after A. Kh. Margulan. Almaty, 2008.

Zuev Ju.A. Ancient Turks: Outlines of History and Ideology. Almaty, 2002. 338 p.

Zuev Ju.A. Chinese Journal about Suyab. Pub. house of KazSSR Academy of Sciences: Series on History, Archaeology and Ethnography. Almaty, 1960. No. 3(14). P. 90-93. 